\title{
The uptake of radioactive copper by the brain and other tissues of the developing rat
}

\author{
BY DEIRDRE RYAN AND P. J. WARREN \\ Department of Biochemistry, The London Hospital Medical College, London, $E \mathbf{~}$
}

(Received 7 November 1969-Accepted 26 fanuary 1970)

\begin{abstract}
I. ${ }^{64} \mathrm{Cu}$ as copper chloride in aqueous solution was given by intraperitoneal injection to rats varying in age from a few hours to 14 weeks. The isotope was allowed to circulate in the body for $24 \mathrm{~h}$.

2. The amount of gamma radioactivity present in the brain and blood was measured and the percentage of the initial dose present was calculated. It was shown that the brain ${ }^{64} \mathrm{Cu}$ activity reached a maximum around the 16 th day of life and that the blood showed a steady decrease in the ${ }^{64} \mathrm{Cu}$ activity per $\mathrm{g}$ from birth to maturity. Measurements were also made on the liver and kidney.

3. The excretion of ${ }^{84} \mathrm{Cu}$ in the urine and faeces in $24 \mathrm{~h}$ was also studied. Approximately $30 \%$ of the isotope was excreted in that time, mostly in the faeces.

4. A limited number of experiments in three different age groups were carried out to discover whether changes in specific activity of the isotope given to rats had a significant effect on the percentage of ${ }^{64} \mathrm{Cu}$ taken up by the brain and blood. No such effect was seen.
\end{abstract}

The normal growth and development of vertebrates appear to require the presence of small amounts of copper. In certain species, particularly lambs, this element has been shown to be important in the development of the central nervous system (Fell, Mills \& Boyne, I965). A deficiency of $\mathrm{Cu}$ in the diet produces marked changes in the metabolism of the nervous system, notably a greatly reduced cytochrome oxidase activity (Gallagher, Judah \& Rees, $1956 a$ ), which can be explained by the fact that $\mathrm{Cu}$ forms an integral part of the cytochrome oxidase molecule (Wainio, Wende \& Shimp, 1959) and a depression of phospholipid synthesis. The failure to form phospholipids at normal rates in $\mathrm{Cu}$-deficient rats has been traced to a specific step in their synthesis, concerned with the attachment of CoA-activated fatty acids to $\alpha$-glycerophosphate to form phosphatidic acids (Gallagher, Judah \& Rees, r956b). The definition of the exact role of $\mathrm{Cu}$ in this connexion has not been elucidated.

Depression of cytochrome oxidase activity has also been observed in the liver and kidney of rats on a Cu-deficient diet (Gallagher et al. 1956a) and of the pig (Gubler, Cartwright \& Wintrobe, I957). Howell \& Davison (1959) demonstrated a marked reduction in the activity of cytochrome oxidase in the brain and, to a lesser extent, in the liver of lambs affected with the demyelinating disease known as swayback. Mills 8 Williams (I962) showed a reduction in cytochrome oxidase activity in the brain stem of such lambs. These workers also proved that, with regard to the integrity and function of the central nervous system, the brain $\mathrm{Cu}$ values were of greater significance than those of the liver. Although demyelination has not been demonstrated in rats on a $\mathrm{Cu}$-deficient diet, it has been induced by repeated administration of cyanide, which is known to inhibit aerobic respiration acting particularly on the cytochtome oxidase system (Lumsden, 1950). 
Because of the part played by $\mathrm{Cu}$ in the formation and maintenance of myelin, we considered that a study of the uptake of administered ${ }^{64} \mathrm{Cu}$ by the tissues of rats of different ages, with special emphasis on the uptake of the isotope by the brain during the myelination period, would be of interest. In the rat, myelination takes place after birth, starting in the first few days of life and continuing for about $30 \mathrm{~d}$. The fastest rate of production of myelin by the glial cells occurs at about the $5_{5}$ th day (Dobbing, r967).

\section{EXPERIMENTAL}

\section{Animals and diets}

Two hundred and ten male albino rats, Sprague-Dawley strain, were divided into a number of age groups ranging from a few hours to 14 weeks. Before and during the experiments the adult rats were fed on a standard ration (rat cake 86; Dixon and Sons, Ware, Herts.) containing I I $\mu \mathrm{g} \mathrm{Cu} / \mathrm{g}$, and tap-water ad lib. Young animals were weaned at $2 \mathrm{I}$ and then given the same diet as the adults.

The exact ages of rats up to 4 weeks old were known. Above this age the rats in each group were weighed individually and the average weight of each group was calculated. The age of each group was determined from the average body-weight. The values for this were obtained by measuring the weight of twelve male rats of the same strain at weekly intervals. These rats were given the same diet and kept under the same conditions as the rats used in the experiments.

\section{Isotope administration}

The ${ }^{64} \mathrm{Cu}$ as $\mathrm{CuCl}_{2}$ in aqueous solution (from the Radiochemical Centre, Amersham) was made up in isotonic saline and administered to the animals by intraperitoneal injection. The solutions were obtained weekly and their specific activities, measured at 12.00 hours on the day of injection, varied greatly from sample to sample. The highest specific activity was $3 \mathrm{I} \cdot 3 \mathrm{mCi} / \mathrm{mg}$, the lowest $2 \cdot 7 \mathrm{mCi} / \mathrm{mg}$ and the average of all the solutions used $7.3 \mathrm{mCi} / \mathrm{mg}$. The rats were injected at 15.00 hours. In general we tried to inject a dose of approximately $25 \mu \mathrm{Ci}{ }^{64} \mathrm{Cu} / \mathrm{I} 00 \mathrm{~g}$ body-weight. However, for some of the younger age groups we had to increase the radioactive dose given to the rats to enable the resultant activity of the tissues to be detected by the counting equipment. Hence, throughout the experiments the dose of the isotope given to the rats ranged from 20 to $60 \mu \mathrm{Ci} /$ roo $\mathrm{g}$ body-weight.

\section{Expt I}

\section{Procedure}

The rats were killed by a blow on the neck and decapitated $24 \mathrm{~h}$ after administration of the isotope. Rats under 3 weeks old were killed by direct decapitation. As much blood as possible was collected through a small polyethylene funnel into a glass bottle The liver, kidneys and brain were then removed and placed in $10 \mathrm{ml}$ glass Universal containers.

Collection of urine and faeces. Pairs of rats, varying in age from 3 to 14 weeks were kept in glass metabolism cages (Metabowls; Jencons Scientific Ltd) for $24 \mathrm{~h}$ after 
injection of the isotope. The urine and faeces were collected and placed in glass Universal containers.

The gamma radioactivity of each sample was measured by means of a 'coronet' arrangement of eight Geiger-Müller counting tubes $\left(\mathrm{G}_{4} \mathrm{~Pb}\right.$; 2oth Century Electronics) connected to conventional counting equipment. The average value of the activity measured for each group was calculated and used to express the uptake of ${ }^{64} \mathrm{Cu}$ by the tissues as the mean percentage of the dose.

\section{Expt 2}

Because of the variation in specific activity of the isotope solutions used and the increase in the amount of ${ }^{64} \mathrm{Cu} / \mathrm{roO} \mathrm{g}$ body-weight given to the smaller rats, three sets of experiments were done to study the effect of varying the amount of ${ }^{64} \mathrm{Cu}$ and total $\mathrm{Cu}$ administered on the percentage of the dose present in the tissues after $24 \mathrm{~h}$. In these experiments groups of rats of the same age were injected with varying amounts of $\mathrm{Cu}$ and ${ }^{64} \mathrm{Cu}$. The radioactivity in the tissues was determined and the results were expressed as in Expt $\mathbf{I}$.

\section{RESULTS}

\section{Expt $\mathrm{I}$}

The variation in the percentage of initial dose present after $24 \mathrm{~h}$ with age differed in all the tissues studied. In the kidney there was a small but steady increase in uptake with age, ranging from $1.00 \%( \pm 0.20)$ for the youngest rats studied to $6.52 \%$ $( \pm 0.64)$ for the oldest. The percentage of the initial dose in the liver rose during the

Table 1. Expt 1. Percentage of the initial dose of ${ }^{64} \mathrm{Cu}$ present in the blood and brain of rats of different ages $24 h$ after intraperitoneal injection of the isotope

(Mean values and standard deviations; number of observations shown in parentheses)

\begin{tabular}{rll}
$\begin{array}{r}\text { Rat age } \\
\text { (d) }\end{array}$ & Blood (per g) & \multicolumn{1}{c}{ Brain } \\
0 & - & $0.410 \pm 0.060(7)$ \\
3 & - & $0.560 \pm 0.114(8)$ \\
4 & $2.47 \pm 0.43(4)$ & $0.683 \pm 0.150(8)$ \\
8 & $2 \cdot 22(1)^{*}$ & $0.733 \pm 0.158(8)$ \\
14 & $1 \cdot 30 \pm 0.45(8)$ & $0.828 \pm 0.148(7)$ \\
15 & $1 \cdot 10(1)^{*}$ & $0.889 \pm 0.195(7)$ \\
16 & $1 \cdot 24 \pm 0.40(8)$ & $0.854 \pm 0.133(8)$ \\
20 & $1 \cdot 72(1)^{*}$ & $0.770 \pm 0.145(8)$ \\
22 & $1 \cdot 51 \pm 0.90(18)$ & $0.806 \pm 0.206(23)$ \\
26 & $1 \cdot 25 \pm 0.65(5)$ & $0.542 \pm 0.124(7)$ \\
28 & $1 \cdot 26 \pm 0.39(14)$ & $0.344 \pm 0.151(22)$ \\
30 & $0.80 \pm 0.13(5)$ & $0.264 \pm 0.050(5)$ \\
34 & $1.62 \pm 0.82(4)$ & $0.212 \pm 0.067(4)$ \\
36 & $1 \cdot 07 \pm 0.53(16)$ & $0.187 \pm 0.098(15)$ \\
45 & $0.39 \pm 0.09(15)$ & $0.092 \pm 0.03(15)$ \\
47 & $0.32 \pm 0.09(16)$ & $0.076 \pm 0.014(15)$ \\
50 & $0.45 \pm 0.19(15)$ & $0.116 \pm 0.039(15)$ \\
56 & $0.38 \pm 0.17(6)$ & $0.073 \pm 0.027(6)$ \\
61 & $0.28 \pm 0.04(8)$ & $0.068 \pm 0.011(8)$ \\
100 & $0.22 \pm 0.03(8)$ & $0.047 \pm 0.008(8)$ \\
& &
\end{tabular}


first few days of life from $15.64 \%( \pm \mathrm{r} \cdot 97)$ to a peak of $33.15 \%( \pm 6.03)$ and then dropped to a value of approximately $12 \%$ around the 3 rd week. This value remained constant throughout the rest of the experiments.

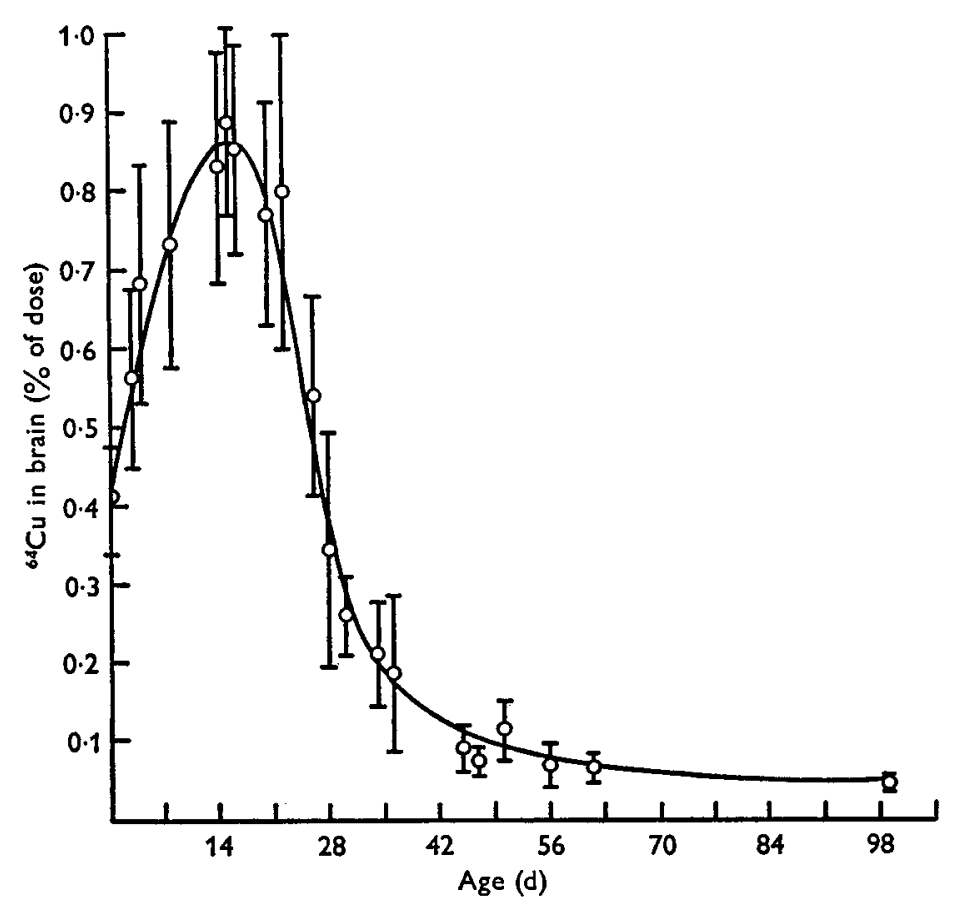

Fig. I. Relationship in rats between ${ }^{84} \mathrm{Cu}$ activity of whole brain (expressed as percentage of initial dose $24 \mathrm{~h}$ after injection) and age. The vertical lines represent the standard deviations.

The results for the brain and blood showed a more interesting pattern than those for the liver and kidney, and their values, together with the standard deviations of the means, are given on Table $\mathbf{r}$. The results are tabulated according to the age of the rat, and the number of observations made on each age group is also given.

Brain. Fig. I shows the graph obtained by plotting the age of the rat against the percentage of the dose present in the brain. The brain contained the least amount of the isotope (less than $\mathrm{I} \%$ ) but the value showed the most dependence on age. The percentage of the dose present in the brain rose sharply during the first 2 weeks of life until about the $\mathrm{I}_{5}$ th day. It then fell steeply during the next few weeks and then more gradually until approximately the 7 th week, when the level remained more or less constant. This value was approximately $5 \%$ of the maximum value.

Blood. In studying the percentage of the initial activity in blood the final results were calculated in terms of percentage ${ }^{64} \mathrm{Cu}$ uptake per $\mathrm{g}$ blood. This was done to compensate for the wide variation in the amount of blood collected from each rat. Fig. 2 shows the relationship between the age of the rats and the percentage of the dose present in I $\mathrm{g}$ of blood. The blood from rats less than $4 \mathrm{~d}$ old was not studied, but in older rats the percentage ${ }^{64} \mathrm{Cu}$ uptake per $\mathrm{g}$ blood was inversely proportional to the age of the animal. 
Urine and faeces. The amounts of urine and faeces collected from each rat varied widely, as did the ${ }^{64} \mathrm{Cu}$ activity of the samples. No appreciable variation with age was observed and the average of all the results obtained was calculated. Approximately $30 \%$ of the total injected isotope was excreted during the $24 \mathrm{~h}$ period. Most of this $(26 \%)$ was found in the faeces.

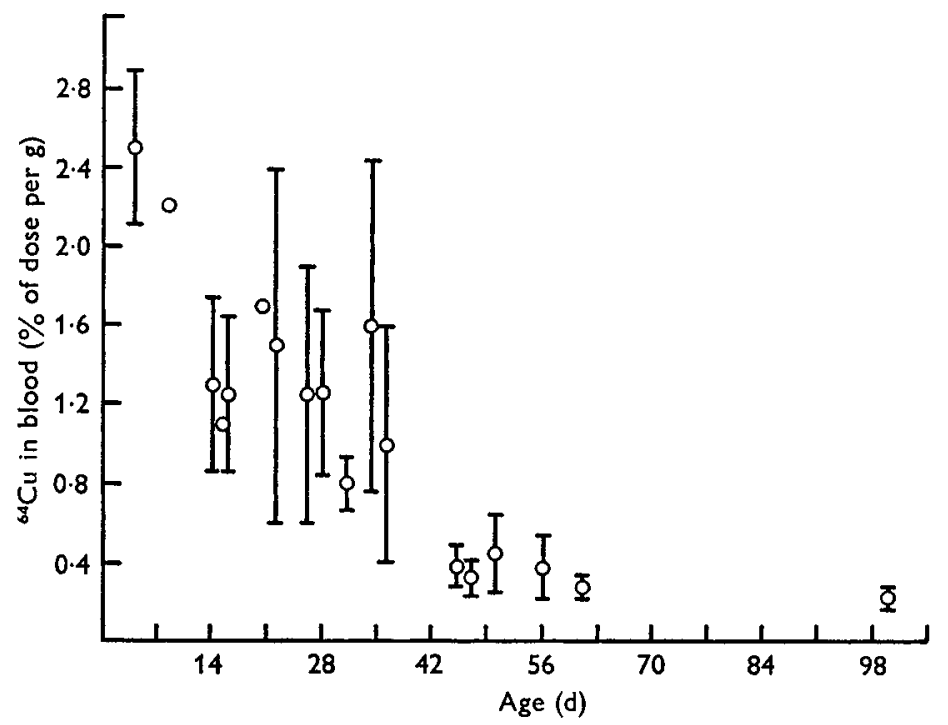

Fig. 2. Relationship in rats between ${ }^{64} \mathrm{Cu}$ activity of blood (expressed as percentage of initial dose per $\mathrm{g} 24 \mathrm{~h}$ after injection) and age. The vertical lines represent the standard deviations.

Table 2. Expt 2. Effect of varying the dose of total $\mathrm{Cu}$ and ${ }^{64} \mathrm{Cu}$ on the percentage of ${ }^{64} \mathrm{Cu}$ present after $24 \mathrm{~h}$ in the brain and blood of rats

(Mean values and standard deviations; number of observations in parentheses)

\begin{tabular}{|c|c|c|c|c|}
\hline \multirow{2}{*}{$\begin{array}{l}\text { Rat age } \\
\text { (d) }\end{array}$} & \multirow{2}{*}{$\begin{array}{c}\text { Total } \mathrm{Cu} \\
\text { administered } \\
(\mu \mathrm{g})\end{array}$} & \multirow{2}{*}{$\begin{array}{c}\text { Dose }{ }^{64} \mathrm{Cu} \\
(\mu \mathrm{Ci})\end{array}$} & \multicolumn{2}{|c|}{$\%$ of initial activity in } \\
\hline & & & Blood (per g) & Brain \\
\hline 24 & $\begin{array}{r}2 \cdot 4 \\
10.4\end{array}$ & $\begin{array}{l}12 \cdot 5 \\
28 \cdot 2\end{array}$ & $\begin{array}{l}I \cdot 22 \pm 0.43(7) \\
I \cdot 25 \pm 0.65(5)\end{array}$ & $\begin{array}{l}0.451 \pm 0.147(7) \\
0.542 \pm 0.124(8)\end{array}$ \\
\hline 36 & $\begin{array}{l}0.8 \\
6 \cdot 7\end{array}$ & $\begin{array}{l}25 \\
50\end{array}$ & $\begin{array}{l}0.92 \pm 0.17(7) \\
I .20 \pm 0.71(8)\end{array}$ & $\begin{array}{l}0.161 \pm 0.048(8) \\
0.212 \pm 0.130(8)\end{array}$ \\
\hline 45 & $\begin{array}{l}8 \cdot 4 \\
35 \\
35\end{array}$ & $\begin{array}{r}50 \\
150 \\
284\end{array}$ & $\begin{array}{l}0.35 \pm 0.08(8) \\
0.33 \pm 0.06(8) \\
0.28 \pm 0.08(7)\end{array}$ & $\begin{array}{l}0.081 \pm 0.014(8) \\
0.065 \pm 0.011(7) \\
0.070 \pm 0.011(8)\end{array}$ \\
\hline
\end{tabular}

\section{Expt 2}

Table 2 shows the effect of varying the amount of total $\mathrm{Cu}$ and ${ }^{64} \mathrm{Cu}$ injected on the percentage of the initial dose present in the brain and blood at three different ages. In spite of the considerable variation in the amount of $\mathrm{Cu}$ and ${ }^{64} \mathrm{Cu}$ given, there was no appreciable change in the percentage of the dose present in the tissues. In fact, taking into account the values for the standard deviations of each group, the percentages of 
${ }^{64} \mathrm{Cu}$ present in the blood and brain were found to be independent of the amount of both total $\mathrm{Cu}$ and ${ }^{64} \mathrm{Cu}$ given. The characteristic patterns in the percentage of the initial dose with age cannot be explained by any possible variation in the concentration of the total $\mathrm{Cu}$ or ${ }^{64} \mathrm{Cu}$ injected.

\section{DISCUSSION}

There are many possible hypotheses which may explain the variations with age in the percentage of ${ }^{64} \mathrm{Cu}$ found in the brain after injection. These variations could be due to an early increase followed by a later decrease in the permeability of the bloodbrain barrier at this stage in development or to alterations with age in the content or nature of the ${ }^{64} \mathrm{Cu}$ in the blood, resulting in changes in its availability to the brain. They may be due to an increase in absorption by the brain of specific metabolites, related to a greater rate of development or metabolism during this period, i.e. an influx of certain substances due to an increase in their requirement by the brain.

The possibility that the increase in uptake of ${ }^{64} \mathrm{Cu}$ by the brain is due to a change in the permeability of the barrier seems improbable in the light of recent knowledge. The original idea of the blood-brain barrier, investigated by morphological studies using dyestuffs, being a distinct anatomical structure has been discredited. Dobbing (I96r) suggests that there may be no morphological evidence of a structural barrier. It is postulated that changes in the blood-brain relationship for naturally occurring substances may be explained in terms of the rate of metabolism in the central nervous system during development. Dobbing further suggests that until the rate of entry of a metabolite into the brain can be satisfactorily demonstrated as a restriction on its utilization, it should be assumed that it is a reflection of, rather than a limiting factor in, in vivo cerebral metabolism. Taking the second hypothesis, i.e. relating the uptake of ${ }^{64} \mathrm{Cu}$ by the brain to the ${ }^{64} \mathrm{Cu}$ content of the blood, the findings presented in Figs. I and 2 might be compared. In contrast to the results for brain (Fig. I), where the ${ }^{64} \mathrm{Cu}$ content reaches a peak, the values for blood (Fig. 2) show that the percentage of the initial dose/g blood varied inversely with age. Therefore the changes found in brain cannot be explained by the total ${ }^{64} \mathrm{Cu}$ content of the circulating blood.

The possibility of explaining the pattern of brain ${ }^{64} \mathrm{Cu}$ with age by the nature of the ${ }^{64} \mathrm{Cu}$ in the blood must involve consideration of the $\mathrm{Cu}$ status and the fate of injected $\mathrm{Cu}$ ions in the blood. In the adult rat $\mathrm{Cu}$ is found in the blood, both in the erythrocytes, as the $\mathrm{Cu}$ protein erythrocuprein, and in the plasma, mainly bound to the $\alpha_{2}$-globulin known as ceruloplasmin. A small proportion (less than $5 \%$ ) of the plasma $\mathrm{Cu}$ is probably loosely bound to albumin (Holmberg, I96I). It has not been definitely established which of these forms is the $\mathrm{Cu}$ donor to the tissues. After injection of ${ }^{64} \mathrm{Cu}$ into the adult rat, the erythrocytic ${ }^{64} \mathrm{Cu}$ content is small and the plasma gradually reaches a stage where over $95 \%$ is present as ceruloplasmin. Since the erythrocytes could furnish $\mathrm{Cu}$ to the tissues only if they had a very rapid turn-over of $\mathrm{Cu}$ it seems more likely that the $\mathrm{Cu}$ is donated to the tissues by the plasma. This leaves either the ceruloplasmin or the albumin-bound portion as the $\mathrm{Cu}$ donor to the tissues. It has been suggested by some workers that ceruloplasmin may be the principal $\mathrm{Cu}$ carrier in blood (Holmberg, I96r; Owen, 
1965). Since it is known to be an enzyme with oxidase activity it seems likely that its main importance lies in this role. The function of ceruloplasmin in the blood has not been fully elucidated but it is feasible that the molecule could act as a carrier for $\mathrm{Cu}$. The fact that it is difficult for ceruloplasmin to pass the blood-brain barrier (Burtin, 1959) and that our results showed a much lower ${ }^{64} \mathrm{Cu}$ concentration in brain than in the other tissues studied, may support the hypothesis that ceruloplasmin is the $\mathrm{Cu}$ donor to the tissues. On the other hand, the albumin-bound ${ }^{64} \mathrm{Cu}$ being a smaller molecule with the $\mathrm{Cu}$ more loosely attached may pass more readily through the blood-brain barrier. This theory may be supported by evidence that patients with Wilson's disease have a deficiency or even an absence of ceruloplasmin in the blood (Scheinberg \& Gitlin, I952) a value of albumin-bound $\mathrm{Cu}$ higher than normal (Cartwright, Hodges, Gubler, Mahoney, Daum, Wintrobe \& Bean, 1954) and a greatly raised concentration of $\mathrm{Cu}$ in the brain and other tissues (Cumings, 1948).

Whether the ${ }^{64} \mathrm{Cu}$ is carried by the albumin or the globulin fraction in the blood does not explain the variation with age in the brain ${ }^{64} \mathrm{Cu}$ unless there is some change in the ratio of these two forms during development resulting in a marked increase in the availability of ${ }^{64} \mathrm{Cu}$ during the first few weeks of life with maximum availability around the r6th day. However, Evans \& Wiederanders (1967) have shown that the blood of newborn rats contains scarcely measurable amounts of ceruloplasmin while the value for total plasma $\mathrm{Cu}$ is about half that of adult values. This is due to the fact that the liver of the foetal and newborn rat is unable to synthesize ceruloplasmin. Immediately after birth, traces of ceruloplasmin appear in the blood. The level increases until around the 2oth day when it reaches adult levels. We can conclude, therefore, that in our experiments, after injection of ${ }^{64} \mathrm{Cu}$ into newborn rats, virtually all of the plasma ${ }^{64} \mathrm{Cu}$ remained in the albumin-bound form and that there was a gradual increase in the ratio of ceruloplasmin-bound ${ }^{64} \mathrm{Cu}$ to albumin-bound ${ }^{64} \mathrm{Cu}$ in rats up to $20 \mathrm{~d}$ of age. From this age most of the ${ }^{64} \mathrm{Cu}$ in the plasma was present as ceruloplasmin. Since there is no evidence of one or other of these forms being prevalent around the period of maximum uptake by the brain, we can only conclude that this phenomenon cannot be explained by the nature of the ${ }^{64} \mathrm{Cu}$ in the blood.

Therefore, it seems more likely that the explanation of the marked increase in ${ }^{64} \mathrm{Cu}$ uptake by the brain during the first few weeks of life might be a considerable demand for $\mathrm{Cu}$ during this active period of brain maturation. The similarity of response and timing with the studies that have been made on the rate of synthesis of myelin precursors (Dobbing, 1967) strongly suggests that this influx of $\mathrm{Cu}$ into the brain is concerned with the process of myelination.

The authors wish to thank the Multiple Sclerosis Society for financial support, and Professor F. L. Warren, in whose department this work was carried out. 


\section{REFERENCES}

Burtin, P. (1959). Clinica chim. Acta 4, 72.

Cartwright, G. E., Hodges, R. E., Gubler, C. J., Mahoney, J. P., Daum, K., Wintrobe, M. M. \& Bean, W. B. (1954). \%. clin. Invest. 33, 1487.

Cumings, J. N. (r948). Brain 71, 410.

Dobbing, J. (196r). Physiol. Rev. 41, r3o.

Dobbing, J. (1967). Sci. F. 3, 81.

Evans, G. W. \& Wiederanders, R. E. (1967). Am. F. Physiol. 213, 1177.

Fell, B. F., Mills, C. F. \& Boyne, R. (1965). Res. vet. Sci. 6, I70.

Gallagher, C. H., Judah, J. D. \& Rees, K. R. (I956a). Proc. R. Soc. B I45, I34.

Gallagher, C. H., Judah, J. D. \& Rees, K. R. (1956b). Proc. R. Soc. B 145, 195.

Gubler, C. J., Cartwright, G. E. \& Wintrobe, M. M. (1957). $\mathcal{~ f . ~ b i o l . ~ C h e m . ~ 2 2 4 , ~} 533$.

Holmberg, C. G. (r96I). Wilson's Disease: Some Current Concepts p. 64 [J. M. Walshe and J. N. Cumings, editors]. Oxford: Blackwell.

Howell, J. McC. \& Davison, A. N. (1959). Biochem. F. 72, 365.

Lumsden, C. E. (1950). F. Neurol. Neurosurg. Psychiat. 13, I.

Mills, C. F. \& Williams, R. B. (1962). Biochem. F. 85, 629.

Owen, C. A. Jr (1965). Am. F. Physiol. 209, 900.

Scheinberg, H. \& Gitlin, D. (1952). Science, N.Y. Ir6, 484.

Wainio, W. W., Wende, C. V. \& Shimp, N. F. (1 959). F. biol. Chem. 234, 2433. 